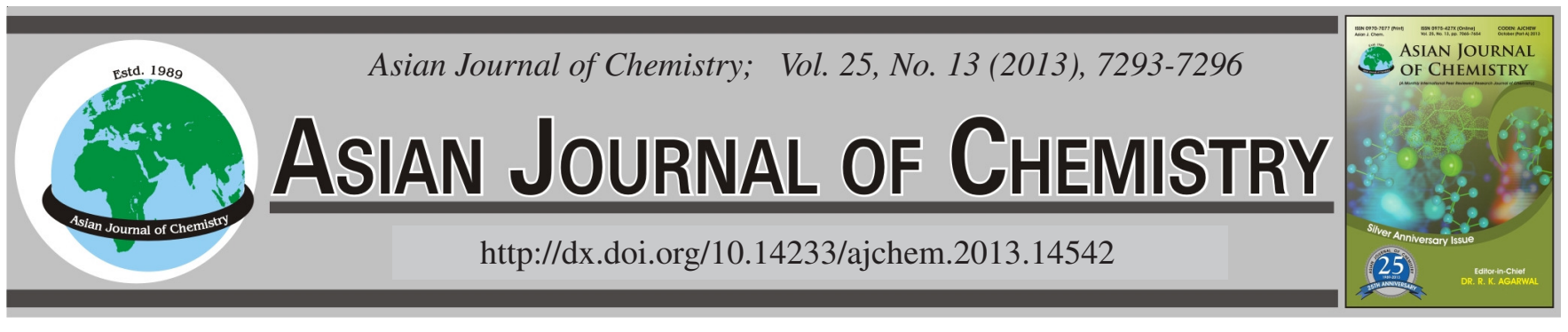

\title{
Synthesis and Characterization of Diaryl Pyrazole-4-carbaldehyde Semicarbazones Metal Complexes
}

\begin{abstract}
Muhammad Nasrullah ${ }^{1}$, Misbahul Ain Khan ${ }^{1}$, Muhammad Naeem Khan ${ }^{2, *}$, Mark G. Humphrey ${ }^{3}$, Umar Farooq ${ }^{4}$,
\end{abstract} Samina Aslam ${ }^{1}$, Muhammad Ahmad $^{1}$, Munawar Ali Munawar ${ }^{4}$, Tahir Maqbool ${ }^{1}$ and Whei-Oh Lin ${ }^{5}$

\author{
${ }^{1}$ Department of Chemistry, The Islamia University of Bahawalpur, Bahawalpur, Pakistan \\ ${ }^{2}$ Applied Chemistry Research Center, PCSIR Laboratories Complex, Lahore, Pakistan \\ ${ }^{3}$ Research School of Chemistry, Australian National University, Canberra, Australia \\ ${ }^{4}$ Institute of Chemistry, University of the Punjab, Quaid-i-Azam Campus, Lahore, Pakistan \\ ${ }^{5}$ Departamento de Quimica, Universidade de Grande Rio, Rua Prof. Jose Hurdy, Duque de Caxias, RJ, Brazil
}

*Corresponding author: E-mail: changwani_1@yahoo.com

Four heterocyclic ligands [1,3-diarylpyrazole-4-carbaldehyde semicarbazones] and their metal complexes with $d$-block transition elements $\left(\mathrm{Cu}^{2+}, \mathrm{Ni}^{2+}, \mathrm{Co}^{2+}, \mathrm{Pb}^{2+}, \mathrm{Zn}^{2+}\right.$ and $\left.\mathrm{Fe}^{2+}\right)$ have been synthesized and characterized through elemental analysis and spectroscopic techniques $v i z .$, FTIR, ${ }^{1} \mathrm{H}$ NMR and mass spectra.

Key Words: Semicarbazones, Vilsmeier-Haack reaction, $d$-Block metal complexes, Pyrazoles and NMR spectra.

\section{INTRODUCTION}

Semicarbazones are commonly used as ligands in coordination chemistry and are biologically active compounds. Their complexation with different metals enhances the bioactivity of these molecules. These metal based complexes have attracted considerable interest in chemical and biological studies due to their potentially beneficial biological activities which may be attributed to formation of their chelates with metal ions $^{1-8}$. In continuation of our previous studies of the metal complexes of diphenylpyrazole compounds ${ }^{9-12}$, we would now like to report the synthesis of some novel metal complexes of diverse 1,3-diarylpyrazole-4-carbaldehydes semicarbazones.

\section{EXPERIMENTAL}

AR grade chemicals purchased from Merck and Aldrich were used in this study. The ${ }^{1} \mathrm{H}$ NMR spectra were recorded on Varian MR Instrument at $300 \mathrm{MHz}$ in $\mathrm{CDCl}_{3}$ using tetramethylsilane (TMS) as internal standard. Electron spray ionization mass spectra (ESI MS) were recorded on VG AutoSpec M series (EBE) MS spectrometer. FTIR spectra were recorded on Bruker Tensor-27. Elemental analyses were performed using Carlo Erba 1106 automatic analyser. Melting points were taken on a GallenKemp melting point apparatus and are uncorrected.
1,3-Diarylpyrazole-4-carbaldehydes (1 and 2): Synthesis of ligands $\mathbf{1}$ and $\mathbf{2}$ has already been reported in a previous publication $^{12}$.

1,3-Diarylpyrazole-4-carbaldehyde semicarbazones (3 and 4): General method: A mixture of 1,3-diarylpyrazole-4carbaldehyde ( $5 \mathrm{mmol})$, semicarbazide hydrochloride (5 mmol) and 3-4 drops of phosphoric acid in ethanol (35 mL), was refluxed for $45 \mathrm{~min}$. After cooling, the mixture was poured into distilled water $(200 \mathrm{~mL})$, off white precipitates were filtered off and recrystallized from ethanol.

The following semicarbazones were prepared in this manner.

1,3-Diphenylpyrazole-4-carbaldehyde semicarbazone (3) Off white crystals, m.p. $202^{\circ} \mathrm{C}$, yield; $1.4 \mathrm{~g} ; 77 \%$.

3-(4'-Chlorophenyl)-1-phenylpyrazole-4-carbaldehyde semicarbazone (4) Off-white crystals, m.p. $208^{\circ} \mathrm{C}$, yield; 1.7 g; $85 \%$.

Synthesis of metal complexes (5-16): General method: Metal(II) chlorides ( $1 \mathrm{mmol}$ ) were dissolved in $10 \mathrm{~mL}$ ethanol and the solution was mixed with a warm ethanolic solution $(25 \mathrm{~mL})$ containing equimolar quantity $(1 \mathrm{mmol})$ of ligands (3 or 4). The mixture was refluxed for $4 \mathrm{~h}$, cooled to room temperature and poured into distilled water $(200 \mathrm{~mL})$ to give crystalline precipitates. These were washed successively with water and ethanol, dried by vacuum suction and stored in a desiccator containing anhydrous calcium chloride. The 
physical and spectral data of complexes is tabulated in Tables 1 and 2 .

\section{RESULTS AND DISCUSSION}

Scheme-I gives the general method for the synthesis of the semicarbazones ligands $\mathbf{3}$ and $\mathbf{4}$. These were obtained in good yields (70-75\%) by the condensation of warm ethanolic solutions of corresponding aldehydes and semicarbazide. Elemental analysis, mass spectra, FTIR and ${ }^{1} \mathrm{H}$ NMR were used to confirm the formation of respective complexes. Physical and Spectral data are tabulated in Tables 1 and 2.

Various metal complexes (5-16) were prepared and characterized through their elemental analysis and spectroscopic data. Atomic absorption spectroscopy was used to determine the metal contents of these complexes and metal to ligand ratio was found to be 1:2. This ratio was also confirmed from mass spectral data and elemental analysis $(\mathrm{CHN})$.

FTIR analysis: The mode of bond formation in complexation between ligand and metal ions can be effectively determined by the FTIR spectra (Table-2). The enolic forms of the ligands (semicarbazones) seem to be more dominant than the ketonic tautomeric forms. This is substantiated by the presence of a broad $\mathrm{OH}$ absorption band for the ligands ( 3 and 4 ) in the region of 3500-3000 $\mathrm{cm}^{-1}$ which is absent in all the complexes (5-16) pointing to an enolic O-bonding to the metal while there is a discreet shift in the carbonyl frequencies of the semicarbazone ligands ( 3 and $\mathbf{4}$ ) as compared with their corresponding metal complexes. The characteristics peaks for $\mathrm{NH}_{2}$ are observed ${ }^{13}$ at 3500-3000 $\mathrm{cm}^{-1}$. The absorption bands around $1660-1590 \mathrm{~cm}^{-1}$ are designated to the azomethine

TABLE-1

PHYSICAL DATA FOR THE LIGANDS AND THE METAL COMPLEXES

\begin{tabular}{|c|c|c|c|c|c|c|c|c|}
\hline \multirow{2}{*}{ Compd. } & \multirow{2}{*}{ Yield $(\%)$} & \multirow{2}{*}{ m.p. $\left({ }^{\circ} \mathrm{C}\right)$} & \multirow{2}{*}{$\mathrm{MS} \dagger$} & \multirow{2}{*}{ m.f. } & \multicolumn{4}{|c|}{ Elemental analysis (\%) Calcd. (Found) } \\
\hline & & & & & M & $\mathrm{C}$ & $\mathrm{H}$ & $\mathrm{N}$ \\
\hline 3 & 88 & 194 & $305 * *$ & $\mathrm{C}_{17} \mathrm{H}_{15} \mathrm{~N}_{5} \mathrm{O}$ & - & $66.87(66.82)$ & $4.95(4.92)$ & $22.94(22.91)$ \\
\hline 5 & 78 & $266 *$ & 673 & $\mathrm{C}_{34} \mathrm{H}_{30} \mathrm{~N}_{10} \mathrm{O}_{2} \mathrm{Cu}$ & $9.43(9.28)$ & $60.57(60.53)$ & $4.48(4.52)$ & $20.77(20.71)$ \\
\hline 6 & 76 & $241 *$ & 668 & $\mathrm{C}_{34} \mathrm{H}_{30} \mathrm{~N}_{10} \mathrm{O}_{2} \mathrm{Ni}$ & $8.77(8.62)$ & $61.01(61.03)$ & $4.52(4.57)$ & $20.93(20.89)$ \\
\hline 7 & 76 & $257^{*}$ & 669 & $\mathrm{C}_{34} \mathrm{H}_{30} \mathrm{~N}_{10} \mathrm{O}_{2} \mathrm{Co}$ & $8.80(8.65)$ & $66.99(66.92)$ & $4.52(4.49)$ & $20.92(20.89)$ \\
\hline 8 & 82 & $234 *$ & 818 & $\mathrm{C}_{34} \mathrm{H}_{30} \mathrm{~N}_{10} \mathrm{O}_{2} \mathrm{~Pb}$ & $25.33(25.20)$ & $49.93(49.95)$ & $3.70(3.73)$ & $17.13(17.15)$ \\
\hline 9 & 74 & $243^{*}$ & 674 & $\mathrm{C}_{34} \mathrm{H}_{30} \mathrm{~N}_{10} \mathrm{O}_{2} \mathrm{Zn}$ & $9.67(9.55)$ & $60.40(60.43)$ & $4.47(4.49)$ & $20.72(20.75)$ \\
\hline 10 & 74 & $251^{*}$ & 666 & $\mathrm{C}_{34} \mathrm{H}_{30} \mathrm{~N}_{10} \mathrm{O}_{2} \mathrm{Fe}$ & $8.38(8.24)$ & $61.27(61.31)$ & $4.54(4.51)$ & $21.01(21.05)$ \\
\hline 4 & 85 & 199 & $339 * *, 341$ & $\mathrm{C}_{17} \mathrm{H}_{14} \mathrm{~N}_{5} \mathrm{OCl}$ & - & $60.09(60.02)$ & $4.15(4.08)$ & $20.61(20.63)$ \\
\hline 11 & 73 & $249 *$ & 741,743 & $\mathrm{C}_{34} \mathrm{H}_{28} \mathrm{~N}_{10} \mathrm{O}_{2} \mathrm{CuCl}_{2}$ & $8.55(8.41)$ & $54.95(54.87)$ & $3.80(3.74)$ & $18.85(18.84)$ \\
\hline 12 & 74 & $251^{*}$ & 736,738 & $\mathrm{C}_{34} \mathrm{H}_{28} \mathrm{~N}_{10} \mathrm{O}_{2} \mathrm{NiCl}_{2}$ & $7.95(7.78)$ & $55.32(55.25)$ & $3.82(3.71)$ & $18.97(18.93)$ \\
\hline 13 & 72 & $247 *$ & 737, 739 & $\mathrm{C}_{34} \mathrm{H}_{28} \mathrm{~N}_{10} \mathrm{O}_{2} \mathrm{CoCl}_{2}$ & $7.98(7.81)$ & $55.30(55.37)$ & $3.82(3.85)$ & $18.97(18.83)$ \\
\hline 14 & 72 & $262 *$ & 886,888 & $\mathrm{C}_{34} \mathrm{H}_{28} \mathrm{~N}_{10} \mathrm{O}_{2} \mathrm{PbCl}_{2}$ & $33.37(33.24)$ & $46.05(46.11)$ & $3.18(3.14)$ & $15.80(15.87)$ \\
\hline 15 & 68 & $246^{*}$ & 742,744 & $\mathrm{C}_{34} \mathrm{H}_{28} \mathrm{~N}_{10} \mathrm{O}_{2} \mathrm{ZnCl}_{2}$ & $8.78(8.59)$ & $54.82(54.87)$ & $3.79(3.81)$ & $18.80(18.77)$ \\
\hline
\end{tabular}

*Decomposed; **Corresponding to $\left[\mathrm{L}^{+}\right]$.

\begin{tabular}{|c|c|c|}
\hline \multicolumn{3}{|c|}{$\begin{array}{l}\text { TABLE-2 } \\
\text { FTIR AND }{ }^{1} \mathrm{H} \text { NMR DATA }\end{array}$} \\
\hline Compd. & $\operatorname{IR}\left(\mathrm{cm}^{-1}\right)$ & ${ }^{1} \mathrm{H}$ NMR data $\delta(\mathrm{ppm})$ \\
\hline 3 & $\begin{array}{l}3340.8(\mathrm{NH} 2), 3176.4(\mathrm{OH}), 1664.8(\mathrm{C}=\mathrm{O}), 1587.7 \\
(\mathrm{C}=\mathrm{N}-\mathrm{N}=\mathrm{C})\end{array}$ & $\begin{array}{l}{ }^{1} \mathrm{H}: 10.05(\mathrm{~s}, 1 \mathrm{H}, \mathrm{NHCO}), 9.24(\mathrm{~s}, 1 \mathrm{H}, \mathrm{CH}=\mathrm{N}), 8.28(\mathrm{~s}, 1 \mathrm{H}, \mathrm{Pz}), 7.26-7.83(\mathrm{~m}, \\
10 \mathrm{H}, \mathrm{Ar}), 5.51\left(\mathrm{~s}, \mathrm{br}, 2 \mathrm{H}, \mathrm{NH}_{2}\right)\end{array}$ \\
\hline 5 & $3353.7\left(\mathrm{NH}_{2}\right), 1663.5(\mathrm{C}=\mathrm{O}), 1591.1(\mathrm{C}=\mathrm{N}-\mathrm{N}=\mathrm{C})$ & - \\
\hline 6 & $3351.8\left(\mathrm{NH}_{2}\right), 1666.6(\mathrm{C}=\mathrm{O}), 1585.8(\mathrm{C}=\mathrm{N}-\mathrm{N}=\mathrm{C})$ & $\begin{array}{l}{ }^{1} \mathrm{H}: 9.23(\mathrm{~s}, 1 \mathrm{H}, \mathrm{CH}=\mathrm{N}), 8.26(\mathrm{~s}, 1 \mathrm{H}, \mathrm{Pz}), 7.26-7.80(\mathrm{~m}, 10 \mathrm{H}, \mathrm{Ar}), 5.50(\mathrm{~s}, \mathrm{br}, \\
\left.2 \mathrm{H}, \mathrm{NH}_{2}\right)\end{array}$ \\
\hline 7 & $3357.7\left(\mathrm{NH}_{2}\right), 1683.7(\mathrm{C}=\mathrm{O}), 1592.1(\mathrm{C}=\mathrm{N}-\mathrm{N}=\mathrm{C})$ & $\begin{array}{l}{ }^{1} \mathrm{H}: 9.57(\mathrm{~s}, 1 \mathrm{H}, \mathrm{CH}=\mathrm{N}), 8.35(\mathrm{~s}, 1 \mathrm{H}, \mathrm{Pz}), 7.26-7.98(\mathrm{~m}, 10 \mathrm{H}, \mathrm{Ar}), 5.90(\mathrm{~s}, \mathrm{br}, \\
\left.2 \mathrm{H}, \mathrm{NH}_{2}\right)\end{array}$ \\
\hline 8 & $3309.7\left(\mathrm{NH}_{2}\right), 1667.9(\mathrm{C}=\mathrm{O}), 1594.8(\mathrm{C}=\mathrm{N}-\mathrm{N}=\mathrm{C})$ & $\begin{array}{l}{ }^{1} \mathrm{H}: 8.89(\mathrm{~s}, 1 \mathrm{H}, \mathrm{CH}=\mathrm{N}), 8.28(\mathrm{~s}, 1 \mathrm{H}, \mathrm{Pz}), 7.26-7.79(\mathrm{~m}, 10 \mathrm{H}, \mathrm{Ar}), 5.10(\mathrm{~s}, \mathrm{br}, \\
\left.2 \mathrm{H}, \mathrm{NH}_{2}\right)\end{array}$ \\
\hline 9 & $3315.7\left(\mathrm{NH}_{2}\right), 1668.7(\mathrm{C}=\mathrm{O}), 1591.8(\mathrm{C}=\mathrm{N}-\mathrm{N}=\mathrm{C})$ & $\begin{array}{l}{ }^{1} \mathrm{H}: 9.04(\mathrm{~s}, 1 \mathrm{H}, \mathrm{CH}=\mathrm{N}), 8.28(\mathrm{~s}, 1 \mathrm{H}, \mathrm{Pz}), 7.26-7.80(\mathrm{~m}, 10 \mathrm{H}, \mathrm{Ar}), 5.75(\mathrm{~s}, \mathrm{br}, \\
\left.2 \mathrm{H}, \mathrm{NH}_{2}\right)\end{array}$ \\
\hline 10 & $3361.6\left(\mathrm{NH}_{2}\right), 1670.8(\mathrm{C}=\mathrm{O}), 1589.7(\mathrm{C}=\mathrm{N}-\mathrm{N}=\mathrm{C})$ & - \\
\hline 4 & $\begin{array}{l}3463.8\left(\mathrm{NH}_{2}\right), 3287.2(\mathrm{OH}), 1682.8(\mathrm{C}=\mathrm{O}), 1594.8 \\
(\mathrm{C}=\mathrm{N}-\mathrm{N}=\mathrm{C})\end{array}$ & $\begin{array}{l}{ }^{1} \mathrm{H}: 8.42(\mathrm{~s}, 1 \mathrm{H}, \mathrm{NHCO}), 8.29(\mathrm{~s}, 1 \mathrm{H}, \mathrm{CH}=\mathrm{N}), 8.14(\mathrm{~s}, 1 \mathrm{H}, \mathrm{Pz}), 7.26-7.78(\mathrm{~m}, \\
9 \mathrm{H}, \mathrm{Ar}), 4.95\left(\mathrm{~s}, \mathrm{br}, 2 \mathrm{H}, \mathrm{NH}_{2}\right)\end{array}$ \\
\hline 11 & $3470.8\left(\mathrm{NH}_{2}\right), 1697.0(\mathrm{C}=\mathrm{O}), 1596.1(\mathrm{C}=\mathrm{N}-\mathrm{N}=\mathrm{C})$ & - \\
\hline 12 & $3491.3\left(\mathrm{NH}_{2}\right), 1687.6(\mathrm{C}=\mathrm{O}), 1589.1(\mathrm{C}=\mathrm{N}-\mathrm{N}=\mathrm{C})$ & $\begin{array}{l}{ }^{1} \mathrm{H}: 8.27(\mathrm{~s}, 1 \mathrm{H}, \mathrm{CH}=\mathrm{N}), 8.16(\mathrm{~s}, 1 \mathrm{H}, \mathrm{Pz}), 7.27-7.79(\mathrm{~m}, 9 \mathrm{H}, \mathrm{Ar}), 4.50(\mathrm{~s}, \mathrm{br}, \\
\left.2 \mathrm{H}, \mathrm{NH}_{2}\right)\end{array}$ \\
\hline 13 & $3472.9\left(\mathrm{NH}_{2}\right), 1695.8(\mathrm{C}=\mathrm{O}), 1590.9(\mathrm{C}=\mathrm{N}-\mathrm{N}=\mathrm{C})$ & $\begin{array}{l}{ }^{1} \mathrm{H}: 8.26(\mathrm{~s}, 1 \mathrm{H}, \mathrm{CH}=\mathrm{N}), 8.13(\mathrm{~s}, 1 \mathrm{H}, \mathrm{Pz}), 7.27-7.79(\mathrm{~m}, 9 \mathrm{H}, \mathrm{Ar}), 4.71(\mathrm{~s}, \mathrm{br}, \\
\left.2 \mathrm{H}, \mathrm{NH}_{2}\right)\end{array}$ \\
\hline 14 & $3470.4\left(\mathrm{NH}_{2}\right), 1698.8(\mathrm{C}=\mathrm{O}), 1596.7(\mathrm{C}=\mathrm{N}-\mathrm{N}=\mathrm{C})$ & $\begin{array}{l}{ }^{1} \mathrm{H}: 8.28(\mathrm{~s}, 1 \mathrm{H}, \mathrm{CH}=\mathrm{N}), 8.11(\mathrm{~s}, 1 \mathrm{H}, \mathrm{Pz}), 7.25-7.74(\mathrm{~m}, 9 \mathrm{H}, \mathrm{Ar}), 4.55(\mathrm{~s}, \mathrm{br}, \\
\left.2 \mathrm{H}, \mathrm{NH}_{2}\right)\end{array}$ \\
\hline 15 & $3472.3\left(\mathrm{NH}_{2}\right), 1699.2(\mathrm{C}=\mathrm{O}), 1598.2(\mathrm{C}=\mathrm{N}-\mathrm{N}=\mathrm{C})$ & $\begin{array}{l}{ }^{1} \mathrm{H}: 8.20(\mathrm{~s}, 1 \mathrm{H}, \mathrm{CH}=\mathrm{N}), 8.11(\mathrm{~s}, 1 \mathrm{H}, \mathrm{Pz}), 7.28-7.76(\mathrm{~m}, 9 \mathrm{H}, \mathrm{Ar}), 4.45(\mathrm{~s}, \mathrm{br}, \\
\left.2 \mathrm{H}, \mathrm{NH}_{2}\right)\end{array}$ \\
\hline 16 & $3479.6\left(\mathrm{NH}_{2}\right), 1700.3(\mathrm{C}=\mathrm{O}), 1597.3(\mathrm{C}=\mathrm{N}-\mathrm{N}=\mathrm{C})$ & - \\
\hline
\end{tabular}




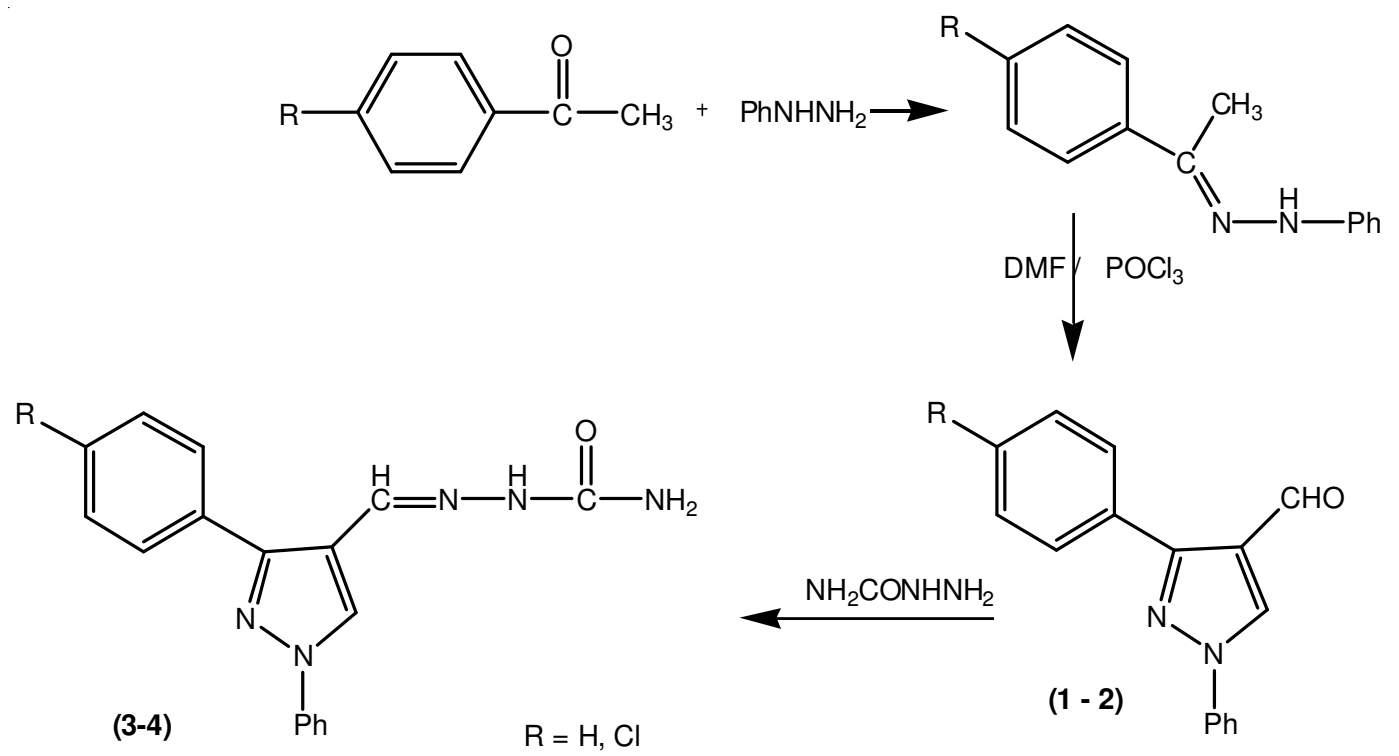

Scheme-I

$(\mathrm{C}=\mathrm{N}-\mathrm{N}=\mathrm{C})$ group $^{14}$. In the complexes, the frequencies of azomethine groups appear mostly towards the lower region which strongly indicates that the ligands coordinate to the metal through the carbonyl oxygen and the azomethine nitrogen of the enolic form of the ligand (Fig. 1). This is further confirmed on the basis of ${ }^{1} \mathrm{H}$ NMR studies. Hence, the ligands act as monobasic bidentate ligands in all the complexes.

${ }^{1} \mathbf{H}$ NMR spectra: The chemical shift values for the ligands (3 and $\mathbf{4}$ ) and the metal complexes are recorded in Table-2. The two ligands differ only in substitution at $4^{\prime}$-position on the 3-aryl substituent in the pyrazole $(\mathrm{Pz})$ ring. The 3-aryl ring protons show multiplets in the 7.20-7.98 ppm region. The characteristic NHCO signal, observed at 10.06 ppm (3 and 4), is conspicuously absent in all the metal complexes (5-16). A broad signal corresponding to $-\mathrm{NH}_{2}$ group in ligands and complexes was also observed between 4.5-6.4 $\mathrm{ppm}^{13}$ and a shift is observed in formation of these complexes. It was further observed that the signals of the protons at NHCO, H-5 proton of pyrazole $(\mathrm{Pz})$ and $4^{\prime}$-substituted phenyl ring were shifted from their original $\delta$ values from the respective ligands (Table-
2). Thus in the formation of complexes of these bivalent metal ions, the NHCO signals disappeared due to enolization of the ligands during complex formation with the help of the carbonyl carbon and azomethine nitrogen of the enolic tautomer $\mathbf{I}$ (Fig. 1).

Electron spray ionization mass spectra: The positive ion ESI MS of the ligands (3 and 4) and their metal complexes (5-16) in $\mathrm{MeOH}$ are dominated by the parent molecular ion peaks. The $\mathrm{m} / \mathrm{z}$ values shown in Table- 1 are $\mathrm{L}^{+}$molecular ion peak for ligands ( $\mathrm{L}$ for ligands) and monopositive complex ion $\left[\mathrm{ML}_{2}+2 \mathrm{H}\right]^{+}$molecular ion peaks. The data support the assumption that metal to ligand ratio is 1:2 in all the complexes.

\section{Conclusion}

The present study revealed that the complexes formed from ligands (3-4) have stoichiometry of 2:1 (ligand:metal) with a possible structure showing chelation through carbonyl oxygen and azomethyne nitrogen structure $\mathbf{I}$ rather than structure II (Fig. 1). These are evidenced by their IR, ${ }^{1} \mathrm{H}$ NMR and elemental analytical data.<smiles>[R]c1ccc(-c2nn(-c3ccccc3)cc2/C=N/N2C[Y16]3(CN=C(N)O3)OC(N)=NN2c2ccc([R])cc2)cc1</smiles>

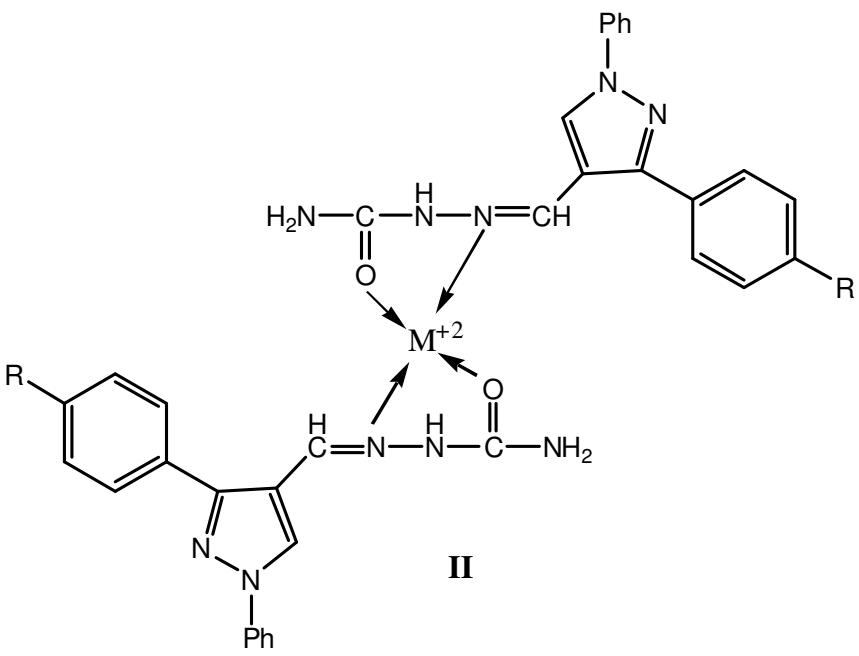

Fig. 1. Structure of metal complexes $(\mathbf{5 - 1 6}), \mathrm{R}=\mathrm{H}, \mathrm{Cl}$ 


\section{ACKNOWLEDGEMENTS}

One of the authors (M. Nasrullah) acknowledges the financial support by HEC Pakistan in the form of an indigenous Ph.D fellowship and assistance in the form of IRSIP to travel and work at Australian National University. Other co-authors (S.A., M.A and TM) also thank HEC for the Indigenous Ph.D. scholarships.

\section{REFERENCES}

1. D.L. Klayman, J.F. Bartosevich, T.S. Griffin, C.J. Mason and J.P. Scovill, J. Med. Chem., 22, 855 (1979).

2. D.X. West, S.B. Padhye and P.B. Sonawane, Struct. Bond., 76, 1 (1991).

3. A.E. Liberta and D.X. West, Biometals, 5, 121 (1992).
4. F.A. French, E.J. Blanz Jr., J.R. DoAmaral and D.A. French, J. Med. Chem., 13, 1117 (1970).

5. H. Beraldo and D. Gambino, Min. Rev. Chem., 4, 31 (2004).

6. S. Rollas and S.G. Kucukguzel, Molecules, 12, 1910 (2007).

7. E.W. Ainscough, A.M. Brodie, W.A. Denny, G.J. Finlay, S.A. Gothe and J.D. Ranford, J. Inorg. Biochem., 77, 125 (1999).

8. D. van Reyk, S. Sarel and N. Hunt, Biochem. Pharmacol., 60, 581 (2000).

9. I. Ahmad, M.A. Khan and M. Ather, Pak. J. Sci. Ind. Res., 43, 38 (2000).

10. I. Ahmad, M.A. Khan and M. Ather, J. Pure Appl. Sci., 17, 67 (1998).

11. I. Ahmad, M.A. Khan and M. Ather, Pak. J. Sci. Ind. Res., 44, 268 (2001).

12. M. Nasrullah, M.A. Khan, M.N. Khan, M.G. Humphrey, F.H. Nasim, F. Choudhry, M.G. Abidi, U. Farooq and M.A. Munawar, Asian J. Chem., 25, 419 (2013)

13. D.L. Pavia, G.M. Lampman and G.S. Kriz, Introduction to Spectroscopy, Thomson Learning Inc., USA (2001).

14. R.T. Conley, Infrared Spectroscopy, Allyn and Bacom Inc., Boston, USA (1972). 